\title{
Current Issues of Construction Law
}

\author{
Dr. iur. Jānis Bramanis \\ Riga Technical University, Latvia \\ janis@bramanis.lv \\ Dr. iur., Professor Jānis Načisčionis \\ ORCID: 0000-0002-6313-8010 \\ "Turība" University, Faculty of Law, Latvia \\ Janis.Naciscionis@turiba.lv
}

\begin{abstract}
Theoretically, the construction right affects all persons and the humanity in general since a situation is impossible that would prove the lack of this process, and as the area of economics, also different economic, political and legal thought development processes regulate consolidation of this legal discipline in the legal science. Construction right has consolidated over time as a legal discipline with its regulating subject - construction works and designing, including also the development of construction plan - designing, construction of the object, reconstruction or dismantling.

Keywords: construction, construction rights, permission, responsibility, construction control.

\section{Introduction}

The author believes that it is difficult to imagine a situation when no construction would be carried out in the country. Thus, the article is of current importance due to several reasons, the main one remaining insufficient attention paid and scientific research undertaken in particular on the subject of the construction right, its content and place in the legal system.

The purpose of the article is to change the approach to construction right and continue specifying its place in the Latvian legal system, simultaneously looking back at the existing solutions to several problems of theoretical and practical nature, which evidently result from the lack of theoretical justification.
\end{abstract}


The study aims at continuing improvement of the construction right theory, while its task is to characterise the development of construction right in Latvia, analyse the legal framework of the construction process in the country and identify the current issues.

Scientific research methods - both comparative and analytical - will be used in the process of drawing up of this publication.

\section{Legal Framework of Construction in Latvia and Theoretical Issues of Its Development}

The legal framework of construction in Latvia and abroad is important, as the society, while being in a public place or in their own private house, need to feel safe, knowing that the erected houses will not collapse and endanger the lives or health. The reason for such statement may be found in the tragedy (Parlamentārās izmeklēšanas komisijas gala ziñojums, 2013) that happened in Latvia where people died in a public space. This tragedy also highlighted the tragedy of the legal framework existing in construction field over many years and the irrational meanders of the legal framework, within which the building specialists involved in the construction process tried to find the most suitable solutions for the construction of the buildings.

Therefore, it is essential to look back at the existing situation with the legal base of construction in Latvia under the context of buildings of public importance, their safety and sustainability, since these are the buildings where most people stay every day, spending time at work, recreating, or just passing by them.

\subsection{Legal Basis of Construction in Latvia (2014-2021)}

The year 2014 is important in the construction law and industry due to the fact that the legislator of the Republic of Latvia (Saeima) chose to cardinally change the legal framework of construction by abandoning years of established practice and gradually abandoning the use of the Soviet Union Construction norms and regulations (Spriedums lietā Nr. A420305714, SKA-1104/2017, 2017) or otherwise known as SNiP during construction process.

The new Construction Law (Būvniecības likums, 2013) entered in force, and with it several subordinate regulatory enactments were created - the Cabinet regulations (Vispārīgie būvnoteikumi, 2014), which significantly changed not only the procedure for obtaining a building permit (the process), but generally the understanding of the role, responsibility and duties of the building specialist in construction process, as well as define the role of the state in control of public buildings.

In this regard, a relevant institution was created - the State Construction Control Bureau of Latvia (Būvniecîbas valsts kontroles biroja nolikums, 2014), the competence of which included control of the construction of public buildings. It must be admitted that as of the moment of drawing up of this publication, the Construction Law has been amended (Būvniecības likums, 2013) ten times. 
It is essential to highlight the changes in relation to the administrative liability in construction, since the Law on Administrative Liability (Administratīvās atbildības likums, 2018) entered in force in 2018, stipulating administrative liability for violations in construction and integrating regulations on administrative liability in the Construction Law (Būvniecības likums, 2013, Articles 25-32).

It has to be pointed out that in this period the legislator finally found a solution for the Eurocodes (Eirokodeksa standartu nacionālais ieviešanas plāns 2013-2014, 2012) that were referred to as standards, by granting them the effect of a legal regulatory enactment. Therefore, a mandatory enforcement effect was given to the long-existing standard.

By granting the effect of a legal regulatory enactment to Eurocodes, at last the designers of building structures acquired legitimate grounds to apply these standards as a mandatory norm not only in the design of public buildings and implementation of this design but also in construction of private houses in general.

\subsection{Development Trends of Legal Construction Norms}

It can be argued that any building and structure acquires its legal status only if it has been designed in accordance with the procedure specified in the laws and regulations and in accordance with the territorial plan, built by fully implementing the approved and accepted construction design and in accordance with the relevant construction norms (Čepāne, 2003). Therefore, when implementing a construction design, a link emerges that a building, built upon a ground and closely connected to it, shall be recognised as its part (Civillikums, 1937, Article 968), which in general creates a whole body - a property.

Therefore, the state is the entity that organises and regulates relations between the subjects of construction rights in order to ensure fulfilment of all the above-mentioned relations and the observance of the requirements. The state should organise stability of relations and create necessary guarantees, as the buildings may have different importance status - a building may be also a building of public importance (Lešinska, Grišāne \& Statkus, 2008), and the requirements for design and construction of the buildings imposed regarding buildings of public importance are rather different and stricter.

Most definitely, the essence of construction rights is manifested in the regulation of relations between construction participants (subjects) or persons whose rights may be violated during construction. Therefore, the legal framework of construction should include also issues related to the construction process in general, including issues related to purchase of land and funding of the project until commissioning of the building or the structure for operation. The legal framework of construction should also include issues regarding conclusion of construction contract, which has not yet been done, the procedure for submission and review of claims or complaints made in construction which affects all parties involved in the construction process. 
Therefore, the following shall be taken into account in the development of building regulations as research objects of construction rights:

1) construction institutions (state and municipal);

2) competence, that is, the goals, tasks, functions, rights, obligations, authorities and responsibility of the subject of construction rights - construction institutions;

3) in the aspect of vertical, horizontal relations of the study of the interaction of separate subjects of construction rights, that is, co-operation relations of subordination and mutual disobedience of construction institutions of higher and lower construction institutions;

4) participation of non-governmental organizations as subjects of construction rights in the relations related to the performance of the functions of construction rights;

5) relations of private persons with the administration of the construction industry;

6) public involvement and rights in the construction process (Bramanis, 2013).

In this regard one of the goals of development of the legal construction norms should be a guarantee - guarantee for the public that buildings or structures involved in the daily life of the society will not cause environmental and public harm and are safe to use.

The construction rights shall address the issue of which rights are more important - the rights of the subject of construction rights, who wishes to build or implement the construction intention or the rights of the person, or who wishes to live in a favourable environment. There are no legally established strict boundaries between these two rights and interests. Therefore, as the guarantee for the public that its rights will be respected, it shall be stipulated that the technical requirements specified in the Latvian building norms shall be complied with the implementation of construction, which, among other things, stipulate that a structure must not be used until it is accepted for service. The structure accepted for service shall be used only according to the designed type of use (Būvniecības likums, 2013, Article 21, Section 2).

Significance of the theoretical aspects of construction rights in the development of construction norms can be found in the search for construction rights, namely, in the law itself as such and in construction law.

\section{Buildings of Public Importance or Public Buildings}

Buildings of public importance or public buildings - the question of which term to use may arise both in daily life and in legal terminology. It is worth studying the equal or different meaning of these concepts "buildings of public importance" or "public buildings", because understanding of the further practical applicability of these concepts probably changes depending on the content of these concepts. 
Buildings of public importance or public buildings also include military objects, state security buildings, buildings, which have been classified as containing state secret (Par valsts noslēpumu, 1996, Article 6), because design and construction of such buildings requires receiving Industrial safety clearance certificate, issued by the Constitution Protection Bureau (Latvijas Republikas Satversmes aizsardzības birojs).

\subsection{Understanding the Concept of Buildings of Public Importance in Regulatory Enactments}

When reviewing both concepts - "buildings of public importance" or "public buildings", it can be concluded that they consist of two parts. A building of public importance consists of "public importance" and "building", whereas public building consists of "public" and "building".

Regardless of the status of the building, pursuant to the normative regulation in construction, a structure is a physical object which has resulted from human activities and is linked to a foundation (ground or bed) (Būvniecibas likums, 2013, Article 3, Section 3).

Pursuant to the special regulations in construction, the structures per se are divided into buildings and engineering structures, which are further divided into groups in accordance with the construction process (Vispārīgie būvnoteikumi, 2014, Annex 1).

As stipulated in paragraph 2.4 of Article 2 of Latvian building norm LBN 208-15 "Public buildings" (Noteikumi par Latvijas būvnormatīvu LBN 208-15..., 2015), a public building is a building where more than $50 \%$ of the total area of the building is occupied by public spaces or spaces designed for the purpose of ensuring public function, or an engineering structure which is designed for public use (for example, concert stages, stadiums).

Thus, due to its public nature a building of public importance will be attended by different groups of people and the special requirements shall be taken into account in regard to safety and accessibility already when designing such building.

As specified, the number of the floors for a public building depends on the built-up intensity of the land plot and building height restrictions in accordance with the territorial plan and building regulations of the relevant municipality and are specified in the detail plan in more specificity if this is necessary in accordance with the regulatory enactments (Noteikumi par Latvijas būvnormatīvu LBN 208-15 ..., 2015, Point 2.1).

Regrading similarities and differences in the concept of a building of public importance or a public building, it is worth looking at the historical regulations. As specified in the regulations of the currently void Cabinet Regulations No 112 "General construction regulations", the term "of public importance" was defined and used therein for marking public buildings, indicating that a building of public importance is a building which has more than five above-ground stories, a public building in which it is intended more than one hundred people shall inhabit concurrently, a production or warehouse building with total area of more than $1000 \mathrm{~m}^{2}$, a tower, as well as 
a bridge, an overpass, a tunnel if it is longer than $100 \mathrm{~m}$, or an underground structure of more than one story. Local governments in the local building regulations may additionally specify structures of public importance in their relevant territory (Vispārīgie būvnoteikumi, 1997).

Whereas, when reviewing the information available in the public space regarding the use of the concept, it shall be concluded that "a building of public importance" is used in most of the publications, and not the term "public building". This might be related to the different understanding of these concepts, since, when using the term "public", it is immediately perceived as important for the society in general.

Therefore, the term "public building" and not "of public importance" shall be further used in this article. An important factor in the operation of the public buildings is correct control thereof not only in construction of such building, but also later during its operation.

\subsection{Control of Buildings of Public Importance as Public Safety}

Control over public buildings shall meet the principle of good administration (Valsts pārvaldes iekārtas likums, 2002, Article 10). The institution responsible for control of public buildings is the State Construction Control Bureau of Latvia, which, in accordance with Article $6 .{ }^{1}$ of Construction Law, has been entrusted with ensuring state control of construction works.

According to the estimates of the operating report of the Bureau and Annual Public Report of 2019 (Būvniecíbas valsts kontroles birojs, 2019), approximately 10,000 public buildings are under the jurisdiction of the Bureau. During the reporting period, 327 decisions were prepared in general, of which 151 decision was made regarding elimination of danger and consequences of arbitrary construction (in 28 cases regarding elimination of danger in mechanical durability and stability of the building, while the rest of the decisions concern elimination of the consequences of arbitrary construction - of which in 74 cases arbitrary construction concern also the load bearing structures of the building).

Construction control, which mostly includes control over the implementation of the construction design on site and the construction process, however, qualitative outcome of the construction works lies in the interests of any Client, that is why the laws and regulations of Latvia stipulate the requirements both regarding achievement of such outcome and the responsible persons. The quality control of construction is ensured by the Main contractor, the specialists involved by the Client, the Construction Board and the State Construction Control Bureau of Latvia.

A construction work manager has a duty to ensure performance of construction work up to the quality in conformity with a building design and plan for performing the work, also by complying with other laws and regulations governing the construction and technologies laid down for the use of construction products. The quality of 
construction work shall comply with the construction work quality indicators laid down in Latvian Construction Standards and other laws and regulations (see Vispārīgie būvnoteikumi, 2014, Point 99).

Each company develops the construction quality control system in accordance with its profile, type and scope of works to be performed. The quality control of construction works includes: preliminary control of construction work performance documentation, delivered construction products and structures, devices, mechanisms and similar equipment; technological control of individual work operations or work processes; final control of the completed work type (to be handed over) or construction work cycle (structural element) (Vispārīgie būvnoteikumi, 2014, Articles 124, 125).

This raises the issue that the concept of quality is mentioned everywhere, but nowhere are the quality parameters specified, nor is it specified, for example, whether someone should inspect these quality control systems of the contractors which are often formal, or what the consequences are if these systems are not essentially implemented in daily work. This issue directly concerns safety and quality of buildings but is not regulated in practice.

The construction work control in accordance with the competence specified in this law is conducted by construction boards, institutions which perform functions of the construction boards, and the building inspectors of the bureau - persons employed at relevant authorities who have acquired the right of independent practice in the field of architecture or construction and are registered with the register of building inspectors. Within the scope of cooperation, the building inspector of the building authority has the right to also visit such structure and construction site during construction work supervision of which is within the competence of the Bureau or another authority carrying out the functions of the building authority, and to provide information thereon to the relevant authorities for further action (Būvniecības likums, 2013, Article 18, Section 1).

A person is confronted with a kind of "construction supervision" daily - someone is checking a student's homework; another one is checking how well the factory-made products are, etc. The same principle applies in construction. A person named in the state laws must check the work of another person, because, unfortunately, human nature proves that if there is no other, higher-ranking person who pushes and expects a certain level from the employee, these quality standards systematically decline. Construction supervision at its root ensures responsibility of the main contractor for his work.

A construction supervisor is a representative of the Client's interests and a trusted partner in the entire construction process from the procurement development until handing over the construction object in accordance with the requirements of the construction design and regulatory enactments. Construction supervision is regulated by the Regulation 500 of the Cabinet of Ministers "General Construction Regulations", in force of 01.10.2014. A construction supervisor has specific duties (Vispārīgie būvnoteikumi, 2014, Point 125). 
A construction supervisor shall be responsible for supervision of the entire construction work at large and control of every stage specified in the plan of construction supervision at the construction site within the time periods provided for in the relevant plan, and also for the conformity of the structure or its part during construction of which the building supervisor has carried out his or her obligations with the building design and the requirements of the initiator of the construction, this Law and other laws and regulations (Būvniecības likums, 2013, Article 19, Section 6).

The purpose of the author's supervision is not to allow arbitrary deviations from the accepted intention and developed building design, and also infringements of the laws and regulations and standards during the course of the construction work (Vispārīgie būvnoteikumi, 2014, Point 102).

Author's supervision is regulated by the Regulation 500 of the Cabinet of Ministers "General Construction Regulations" in force of 01.10.2014.

Author's supervision is performed for:

1) state protected cultural monuments, buildings of second and third group in the territory of the urban construction monument and in the protective zone thereof in conformity with the territorial planning (except for one or two apartment residential buildings and auxiliary buildings);

2) structures of the third group to be newly erected, restored and reconstructed if building permit is required for construction; public structures of the second group if building permit is required for construction: public structures to be newly erected, restored and reconstructed;

3) new residential buildings (except for one or two apartment residential buildings);

4) structures for which environmental impact assessment has been carried out (Vispārīgie būvnoteikumi, 2014, Point 105).

The purpose of author's supervision is to ensure that the erected object on site will be the same, as specified by the author of the construction design in the completed construction design. This means that author's supervision shall be performed by the author of the construction design or its authorised certified person (Vispārīgie būvnoteikumi, 2014, Point 113).

\subsection{Concept of Construction Rights in Latvia}

Pursuant to the current regulations, construction is design and construction works of all types of structures (Būvniecibas likums, 2013, Article 1, Section 12). But in accordance with the definition of construction, proposed by the Latvian encyclopaedia, "construction is the construction of all types of buildings, a branch of the national economy that performs the design, construction, extension and renovation of all types of buildings" (Latvijas enciklopēdija, 2002).

First, the definition of construction describes the concept of construction. Construction as one of the elements of the composition envisages performing an activity works. Secondly, the definition of construction shows that it is a sector of economy. 
The Construction Law adopted in Latvia after the restoration of independence was the first attempt to understand the concept of construction and the legislator has also acknowledged the fact that it is important to determine the content of the concept of construction. The legislator has acknowledged that the necessary activities, the performance of which is recognised as construction, have not been determined. According to the current legal definition, construction is the design and construction works of all types of structures (Būvniecības likums, 2013, Article 1, Section 12).

It may seem that the concepts construction and construction rights are understandable. Although several amendments have been made to the Construction Law, the legal definition of construction has not changed and has remained in its original version. This definition could be considered self-sufficient if it is clear what is meant by structure. It follows from the definition of the current law that anything that is being built, based on the accepted construction design and a building permit, issued in accordance with a particular procedure, shall be subject to construction rights. Therefore, one should be very careful when defining the concept of construction, because anything that will be subject to the construction rights will be interpreted in the future in accordance with this definition.

Construction rights are rights that determine the set of rights and obligations of legal entities in the design and construction works. Thus, it is necessary to analyse the explanation included in other regulatory enactments regarding classification of structures. The regulations "On classification of structures" (Noteikumi par būvju klasifikāciju, 2010) define classification of structures according to their use. The purpose of classification is to ensure unified registration of structures in the Republic of Latvia. The structures and groups of premises are classified in accordance with their form of use or function. Structures, which are being operated or designed for several uses, shall be included in one particular classification position, based on their main use.

Thus, construction activity results in creation of such structures as buildings, residential houses, dwellings, non-residential buildings, civil engineering works, bridges, roads, water dams and other construction objects. Simultaneously, it should be noted that predominantly classification and functions of buildings are necessary for administration of real estate tax. Thus, new norms will be included in the draft law "Construction Law", which envisages dividing structures into four groups (Būvniecības likums 2013, Article 9). As specified in the annotation to the draft law "Construction Law":

\footnotetext{
"this classification is based on the degree of complexity of the construction of the buildings and the potential impact on the environment. An essential criterion in the formation of these groups is the risk factor or hazard that these structures can potentially pose. In view of the above, in order to divide buildings into groups, it is necessary to take into account not only the number of floors and other technical characteristics, but also the function (type of use) and the potential number of people who come into direct contact with these buildings at the same time. Thus, it is also not possible to make a division based only on the classification of buildings. According to these three groups, additional requirements will be set for the construction of the existing buildings or they will be reduced”. (Būvniecības likums, 2013)
} 
As defined in the national programme of construction (Par Būvniecības nacionālo programmu, 2002), one of the most important end products of construction is housing, which is the main provision of the environment necessary for functioning and existence of human life and at the same time one of the indicators of well-being of people. In this context, the European Court of Human Rights has clarified that housing is the right of an individual to live in their own home and to be protected from unwanted interference with the privacy of the home (Augstākās tiesas Senāta Administratīvo lietu departamenta lieta Nr. SKA-120). In particular, construction rights should aim to protect people from imminent dangers that may arise as a result of impact by third parties or nature. In this regard, it should be noted that only a building (dwelling) built in accordance with the law can create a sense of security and protect a person from imminent danger.

The concept of construction also includes the process where legal norms determine procedure for initiating construction, renovation and reconstruction procedures, construction of engineering networks, rights and obligations of the client, rights and obligations of state and municipal institutions, environmental protection conditions and procedures for performance of construction work (Vispārīgie būvnoteikumi, 1997). As the court concluded, "construction is a single, sequential process in which each subsequent decision depends on a previous decision" (Administratīvās rajona tiesas 10.01.2007. spriedums lietā Nr. A42308005). It follows that, in order to discover substantive limits of the concept of construction, it is necessary to identify a set of activities which refer to works, that is to say, those relating to renovation or new construction. Therefore, in order to establish the fact whether construction has taken place or not, a precondition is to establish existence of the activity.

\section{Conclusion}

Consequently, a current issue related to the development of construction law is related to the expertise of construction and construction projects and their place in the construction process as such. The question may arise as to how binding the expert reports commissioned by all participants in the construction process are and the conclusions contained therein.

This would also be relevant in the context of amendments to the Public Procurement Law, which are currently being lobbied by large contractors that in essence they will now hand over everything to customers on the basis of the expertise, and if the customer has any objections, they will have to prove their objections by expertise conclusions.

Such a turnaround essentially paves the way for elimination of author supervision and construction supervision as a system, as the contractor and construction expert(s) will be involved as voting participants in the construction process. This can directly pose a risk to security of public buildings, as public buildings are mainly public procurements regulated by the Public Procurement Law. Combined with the generality of 
the concepts of quality and control and the lack of detailed concepts of responsibility and consequences in the regulations, this creates a situation in which Latvian construction found itself shortly after 2009, when the State Construction Inspectorate was liquidated.

\section{Bibliography}

\section{State Laws}

1. Administratīvās atbildības likums: LR likums, 25.10.2018., stājas spēkā 01.07.2020. Latvijas Vēstnesis, 225, 14.11.2018. https://likumi.lv/ta/id/303007-administrativas-atbildibas-likums.

2. Būvniecỉbas likums: LR likums, 09.07.2013., stājas spēkā 01.10.2014., Latvijas Vēstnesis, 146, 30.07.2013. https://likumi.lv/ta/id/258572-buvniecibas-likums.

3. Civillikums: LR likums, 28.01.1937., stājas spēkā 01.09.1992. Valdības Vēstnesis, 41, 20.02.1937. https://likumi.lv/ta/id/225418-civillikums.

4. Likumprojekts "Būvniecības likums": sākotnējās ietekmes novērtējuma ziṇojums (anotācija).

5. Par valsts noslēpumu: LR likums, 17.10.1996., stājas spēkā 01.01.1997., Latvijas Vēstnesis, Nr. 181, 29.10.1996. https:/likumi.lv/ta/id/41058-par-valsts-noslepumu.

6. Valsts pārvaldes iekārtas likums: LR likums, 06.06.2002., stājas spēkā 01.01.2003., Latvijas Vēstnesis, 94, 21.06.2002.

\section{Regulations of the Cabinet of Ministers}

7. Būvniecības valsts kontroles biroja nolikums: MK noteikumi Nr. 576, 30.09.2014., stājas spēkā 01.10.2014. Vēstnesis, Nr. 194, 01.10.2014. Izdoti saskanāa ar Valsts pārvaldes likuma 16. panta pirmo dalı. https://likumi.lv/ta/id/269202-buvniecibas-valsts-kontroles-biroja-nolikums.

8. Eirokodeksa standartu nacionālais ieviešanas plāns, 2013.-2014. gads: MK 17.05.2012. Rīkojums Nr. 224. http://tap.mk.gov.lv/doc/2005/EMpl_260312_EC.749.docx.

9. Noteikumi par būvju klasifikāciju: MK noteikumi Nr. 1620, spēkā no 01.01.2010. Latvijas Vēstnesis, Nr. 205, 30.12.2009. Izdoti saskaņā ar Valsts statistikas likuma 71. pantu. http:// www.em.gov.lv/images/modules/items/bk_02_06_10.doc.

10. Noteikumi par Latvijas būvnormatīvu LBN 208-15 “Publiskas būves”: MK noteikumi Nr. 331, 30.06.2015., stājas spēkā 01.07.2015. Latvijas Vēstnesis, 125, 30.06.2015. Izdoti saskanāa ar Būvniecības likuma 5. panta pirmās daḷas 3. punktu. https://likumi.lv/ta/id/274995-noteikumipar-latvijas-buvnormativu-lbn-208-15-publiskas-buves.

11. Par Būvniecības nacionālo programmu: MK rīkojums Nr. 478, 30.08.2002. Latvijas Vēstnesis, 04.09.2002., Nr. 125 (2700). Pēdējie grozijjumi 17.09.2003.

12. Vispārīgie būvnoteikumi: MK noteikumi Nr. 112, 01.04.1997., stājas spēkā 01.07.1997., zaudēja spēku 01.10.2014. Latvijas Vēstnesis, 88, 04.04.1997. Izdoti saskaṇā ar Būvniecības likuma 2. panta ceturto dalu. 252. punkts. https://likumi.lv/ta/id/42807-visparigie-buvnoteikumi. 13. Vispārīgie būvnoteikumi: MK noteikumi Nr. 500, 19.08.2014., stājas spēkā 01.10.2014. Latvijas Vēstnesis, Nr. 191, 26.09.2014. Izdoti saskañā ar Būvniecības likuma 5. panta pirmās daḷas 1. punktu. https://likumi.lv/ta/id/269069-visparigie-buvnoteikumi.

\section{State Documentation}

14. Administratīvās rajona tiesas 10.01.2007. spriedums lietā Nr. A42308005. http://www.tiesuprakse.lv/files/AL_1001_raj_A1200-06_3_.pdf. 
Jānis Bramanis, Jānis Načisčionis. Current Issues of Construction Law

15. Augstākās tiesas Senāta Administratīvo lietu departamenta lieta Nr. SKA-120, 16. punkts. http:// www.at.gov.lv/info/archive/department3/2004/.

16. Būvniecības valsts kontroles birojs. Gada publiskais pārskats par 2019. gadu. file://C:/Users/ Janis/Dropbox/My\%20PC\%20(DESKTOP2VJULQ4)/Downloads/bvkb_publiskais_parskats_20191\%20(1).pdf.

17. Latvijas Republikas Augstākās tiesas Administratīvo lietu departamenta 21.12.2017. spriedums lietā Nr. A420305714, SKA-1104/2017.

18. Parlamentārās izmeklēšanas komisijas galaziṇojums.

https://likumi.lv/ta/id/277713-parlamentaras-izmeklesanas-komisijas-par-latvijas-valstsricibu-izvertejot-2013gada-21novembri-zolitude-notikusas-tragedijas-celonus-un\%20turpmakajam-darbibam-kas-veiktas-normativo-aktu-un-valsts-parvaldes-un-pasvaldibu-darbibas\%20 sakartosana-lai-nepielautu-lidzigu-tragediju-atkartosanos-ka-ari-par-darbibam-minetas-tragedijas-seku\%20nov\%C4\%93r\%C5\%A1an\%C4\%81\%20galazi\%C5\%86ojums.

19. Traffic Defense Office of the Republic of Latvia. Industrial safety. https://www.sab.gov. $\mathrm{lv} / \mathrm{a}=\mathrm{s} \& \mathrm{id}=24$.

\section{Literature}

20. Bramanis, J. (2013). Būvniecības tiesību attīstības problemātika Latvijā: Promocijas darbs Biznesa augstskola "Turība".

21. Čepāne, I. (2003). Patvalīga būvniecība, Satversme un vispārīgie tiesību principi. Jurista Vārds, Nr. 36 (294). http://www.juristavards.lv/index.php?menu=DOC\&id=181889.

22. Latvijas enciklopēdija, 1. sēj. (2002). SIA "Valērija Belokoṇa izdevniecība", 927. lpp.

23. Lešinska, A., Grišāne, A., Statkus, S. (2008). Izaicinājums būvēt likumīgi. Būvniecības procesa rokasgrāmata visiem, kas būvē, izdod būvatḷaujas un dzīvo kaimiṇos. Sabiedriskās politikas centrs "Providus", 45.-46. lpp. 